look to establishing closer and more direct contact with Soviet scientific workers engaged with us in a common struggle, as has been done already with the United States, and to hope for similar collaboration in building up a new world in which science will at least be free to devote itself wholeheartedly to the service of humanity. Scientific liaison with the U.S.S.R. may well be an important aid to mutual understanding between the two nations, for if we have much to learn of the Soviet effort it is at least equally true that they have much to learn of Britain.

Prof. Bernal's review of these developments suggests, however, that an even more important postwar consequence may be a much greater general awareness of the importance of science : not merely an appreciation of its achievements but a greater desire to understand its method and possibilities. Mr. J. G. Crowther touched on this educational aspect, more particularly in respect of the opportunities in the munitions industry, in an address which referred to some points made at the British Association Conference last March on "Science and the Citizen" with regard to ways and means of increasing the public understanding and appreciation of science. None the less, the significance of the educational opportunities which the increased operational contacts with science in the Forces and the greater use of scientific instruments and weapons by fighting men themselves offer in respect of the postwar world, scarcely appears to be appreciated. If that opportunity is seized, if every possible means is used, whether now through such means as the Army Education Corps or through the Workers Educational Association and other instruments of adult education after the War, to bring home to the ordinary citizen not merely the achievements but also the nature of science and the limitations as well as the possibilities of the scientific method, we shall have taken a long step towards making it possible for society to enjoy the abundance which science has put within our power.

That achievement depends on the use of science, and our scientific resources for science-like planning -has its dangers and limitations, and Britain and Soviet Russia have much to learn from their widely different experiences. We cannot make full and wise use of science in a democracy without a widespread understanding of what science is, what it can do and what it cannot do, and in this respect it may well be that Britain lags somewhat behind Soviet Russia. What may fairly be open to doubt is, as Prof. Polanyi showed in a recent paper, whether Soviet Russia has always understood the true nature and limitation of the scientific method. Science and politics may be consorts but they are ill-mixers, and science and propaganda go ill together. Quality, not quantity, is the vital element in science.

The eloquent plea for co-operation and mutual understanding between science and government, statesmen and men of science, which was uttered by Mr. J. G. Crowther at the meeting emphasizes a further point which lies behind the effort of Soviet and British scientific workers in the struggle with Germany. Whatever the imperfections or neglect of science in Britain and in Russia, both countries are to-day struggling against a power which has struck at the well-springs of scientific thought and advance. As a cable from the Moscow meeting addressed to the Association stated, the Nazis have set themselves deliberately to extinguish the torch of knowledge. Their regime threatens the very existence of scientific life and thought, and while that threat remains there can be no security for the free spirit of inquiry, the patient, independent investigation and creative thought which are the essence of science and the secret of its advance. That challenge has been taken up wholeheartedly by British and by Soviet scientific workers, and the meetings in Moscow and in London on July 11 attest their sincerity and determination. Scientific workers, in addressing themselves to their wider tasks and in accepting wholeheartedly their social responsibilities, must remember also that it is their prime responsibility to guard and cherish that unfaltering quest for truth which is at the heart of science, and to make sure that in all their organization and planning they consent to nothing that impairs their freedom of inquiry or utterance and the ultimate but fundamental loyalty to truth.

\section{CLINICAL PHOTOGRAPHY}

A $\mathrm{T}$ a meeting of the Association for Scientific A Photography held on September 18 at Middlesex Hospital, Dr. H. Mandiwall stressed the particular qualities required in elinical photography. In his opinion these are : (a) a simple straightforward record with perfect definition; (b) a self-explanatory picture, but nevertheless one which does not include unessential portions; (c) a well-presented print, as much care being taken in the mounting and finishing as in a studio portrait; $(d)$ in the case of colour photographs, the colour must be true to the original. This is of particular importance in skin diseases which are characterized by the colours of the part affected. It was suggested that a Clinical Group should be formed in the Association, which would discuss the special aspects of this work, and compare technique.

Another point was the collaboration between photographers and manufacturers of apparatus. The requirements of clinical photography are in many cases distinct from those of studio or outdoor work, and it would be of great advantage to have certain apparatus specifically designed for the work.

In opening the meeting, Mr. T. Pomfret Kilner stressed the importance of standardization in technique, particularly in his own sphere of plastic surgery. The photographs taken before and after treatment must be strictly comparable as regards type of film, exposure, lighting, etc. He illustrated his remarks with views of a simple equipment employ. ing a Leica camera and photoflood lighting which enables photographs to be taken at any angle and can also be used for copying radiographs or documents. He recommended that Ortho materials be used for the majority of work; previous to the War, he had always used Agfa Isochrom film.

Miss Hilda Marsden showed examples of the work done in clinical photography at the Christie Hospital, Manchester, using a half-plate camera with studio technique. She laid special stress on the importance of lighting, particularly in delineating the outlines of growths, etc.

In the discussion which followed the papers, Mr. J. E. Andrews showed illustrations of a convenient set-up for photographing patients in bed which was made with the aid of a pair of steps such as is always available in a hospital. The camera was fitted to the top of the steps with the usual ball-and-socket joint and could be directed in any required position. By means of interchangeable lenses and lights also fitted to the top of the steps at varying angles, he was 
able to take a variety of photographs of a patient from head only to full-length. He had found that a 48-in. lens was adequate for full-length and an 8-in. for head and shoulders. A 14-in. lens gives a close-up of an individual part with the patient lying flat about $5 \mathrm{ft}$. below the camera.

As a matter of interest, Mr. Andrews showed a photograph of a patient with one brown eye and one blue, taken with orthochromatic film without a filter. Only one photoflood lamp was used, and the colour rendering was excellent.

Mr. K. Hennell (Metal Box Co.) said that he had taken several thousand clinical photographs during the War in colour, and used Sashalite bulbs exclusively for illumination. He considered this was the best method for tackling a variety of jobs and agreed with Mr. Kilner concerning the necessity for standardization. $\mathrm{He}$ exhibited several samples of colour prints on paper.

It was in the discussion generally agreed that clinical photography should be undertaken by a professional photographer who would find it advantageous to make a special study of physiology and anatomy. It was not considered reasonable to expect a medical man or surgeon to do his own routine photography, and it was also pointed out that the majority of hospitals, while equipped for X-ray work, are not well equipped for clinical photcgraphy.

Those interested in the formation of a Clinical Photography Section should write to the secretary of the Association, Mr. R. M. Weston, at Houndwood, Farley, Nr. Salisbury, Wilts.

\section{REHABILITATION OF THE 'SCORCHED EARTH' IN THE U.S.S.R.}

$\mathrm{T}$ HE preliminary arrangements have recently been announced by the Soviet Government for the rehabilitation of the different regions of the U.S.S.R. as they are liberated from the Germans. A Commission has been set up representing forestry, timber supply and other interests to arrange for the erection of buildings on the collective farms and of dwellings for the workers. Use is to be made of local supplies of brick or artificial stone of various kinds, and of houses prefabricated in factories : the standard is to be a flat for four families, and thirteen factories are to be put into operation with a capacity of eighty flats per month. The Agricultural Bank will allow 10,000 roubles credit to each family for a period of seven years.

Railways also are to be restored, and dwellings for the staff and the various establishment shops and buildings are to be erected.

Such live-stock as were driven eastwards are to be restored, and regulations have been drawn up for the movement of specified numbers of the animals from seventeen of the reception areas to collective farms in specified regions including Orel, Smolensk, Voronezh, Stalingrad, Rostov, and Stavropol : impressive totals are involved, including 206,000 cattle, $\mathbf{3 4 2 , 0 0 0}$ sheep and goats and 53,000 horses, though these represent only a fraction of the peace-time numbers of animals in these regions. Collection of the animals at specified points in the reception areas was to be completed by September 1, and they were to reach their destination between October 1 and 15 . The difficulties will be considerable, but the routes have been worked out : the journey for the animals is in some cases 800 miles. Arrangements have been made for feeding and watering the animals during their journey and for checking the numbers and duly accounting for their arrival. The risk of carrying disease will be very great, but fifty veterinary surgeons (1 for each 12,000 animals) and a hundred assistants are to be seconded from the reserve of the Red Army and distributed along the routes. In order to ensure further attention when the animals reach their destination, schools are to be set up in each liberated province giving veterinary courses varying in duration from three to twelve months. The Agricultural Publishing House is to be given 50 tons of paper for the printing of instructional literature. Other decrees deal with the provision, payment and transport of the drovers.

Collective farms are being recommended to keep all male calves of 1942 and 1943 to become working oxen.

In the case of poultry, it was necessary to establish incubator and poultry-breeding stations sufficient to deal with 16 million eggs: the aireraft industry was instructed to supply the thermostats and thermometers. The number of specialists required will be considerable: 130 are to be detailed for the new stations, but this number will not suffice, and it is proposed to start courses for training a further 580. In order to ease the work of the collective farms as they are re-established, considerable exemptions during the first year are permitted from the deliveries required to be made by the farm to the State; these apply to farms that have suffered from enemy occupation and households that have suffered bereavement or in which the able-bodied members belong to a specified group of experts. Tractor maintenance and repair stations are to be set up, and schedules are issued of spare parts, etc., that must be stocked.

Special provision is made for supplying railway workers with allotments of about one-third acre on which they may grow what crops they like. These plots are to be exempt from compulsory deliveries to the State: they are to be supplied with seeds, pigs and chickens. Provision is also to be made for the education of orphans and children of Red Army men and partisans; there are to be nine 'Suvorov' military schools, somewhat like the old cadet schools, each for about five hundred boys; and twelve 'industrial' schools for boys from the age of ten and for girls from the age of eleven. Co-education is not adopted in these new schools. Houses for 16,300 children are to be set up.

\section{LIGHTNING PROTECTION OF BURIED CABLE}

GOR the new toll facilities now being installed in H the United States, much of the cable is laid underground to secure greater immunity from effects of sleet, snow, and storms. Burying the cable alone is not necessarily sufficient to free it from the effects of lightning damage. Moreover, when lightning damage such as fusing of cable pairs or holes in the sheath does occur, it is not so easy to locate and repair as on aerial cables since excavations may have to be made at a number of points. As a result of this situation, studies have been made of the factors affecting damage of buried cables by lightning, and 